\title{
Thermosipho geolei sp. nov., a thermophilic bacterium isolated from a continental petroleum reservoir in Western Siberia
}

\footnotetext{
1 UMR 6539, Centre National de la Recherche Scientifique and Université de Bretagne Occidentale, Institut Universitaire Européen de la Mer, Place Nicolas Copernic, 29280 Plouzané, France

2 Institute of Microbiology, Russian Academy of Sciences, Prospect 60-letiya Oktyabrya 7/2, 117811 Moscow, Russia

${ }^{3}$ DSMZ - Deutsche Sammlung von Mikroorganismen und Zellkulturen, Mascheroder Weg 1b, 38124

Braunschweig, Germany

4 Laboratoire IRD de Microbiologie des Anaérobies, Université de Provence, CESB-ESIL, case 925, 163 Avenue de Luminy, 13288 Marseille cedex 9, France
}

\author{
S. L 'Haridon, ${ }^{1}$ M. L. Miroshnichenko, ${ }^{2}$ H. Hippe, ${ }^{3}$ M.-L. Fardeau, ${ }^{4}$ \\ E. Bonch-Osmolovskaya, ${ }^{2}$ E. Stackebrandt ${ }^{3}$ and C. Jeanthon ${ }^{1}$
}

Author for correspondence: C. Jeanthon. Tel: +33298498 751. Fax: +33298498705. e-mail: Christian.Jeanthon@univ-brest.fr

Keywords: oilfield, thermophiles, 'Thermotogales', Thermosipho, Thermosipho geolei

\section{INTRODUCTION}

Members of the order 'Thermotogales' are rod-shaped bacteria that are morphologically characterized by an outer sheath-like structure called a toga (Huber \& Stetter, 1992). These strictly anaerobic thermophiles represent, along with Desulfurobacterium thermolithotrophum and the 'Aquificales', one of the deepest phylogenetic branches in the bacterial line of evolutionary descent (Achenbach-Richter et al., 1987; Burgraff et al., 1992; L'Haridon et al., 1998). At present, the order 'Thermotogales' includes only one family, the 'Thermotogaceae', which consists of five genera: Fervidobacterium (Patel et al., 1985), Thermotoga (Huber et al., 1986), Thermosipho (Huber et al., 1989; Ravot et al., 1996a), Geotoga and Petrotoga (Davey et al., 1993). These obligately heterotrophic

The GenBank accession number for the 16S rRNA gene sequence of strain $\mathrm{SL} 31^{\top}$ is $\mathrm{AJ} 272022$ bacteria have been isolated from and/or detected using molecular techniques in shallow and deep marine hydrothermal vents as well as in continental springs and petroleum reservoirs (Huber et al., 1986, 1989, 1990; Jannasch et al., 1988; Windberger et al., 1989; Davey et al., 1993; Stetter et al., 1993; Jeanthon et al., 1995; L'Haridon et al., 1995; Ravot et al., 1995; Andrews \& Patel, 1996; Grassia et al., 1996; Magot, 1996; Antoine et al., 1997; Fardeau et al., 1997; Koch et al., 1997; Harmsen et al., 1997; Lien et al., 1998; Slobodkin et al., 1999; Corre, 2000; Orphan et al., 2000; Takahata et al., 2000; Takai \& Horikoshi, 2000). The genus Thermosipho contains three validly described species, Thermosipho africanus (Huber et al., 1989; Ravot et al., 1996a), Thermosipho melanesiensis (Antoine et al., 1997) and Thermosipho japonicus (Takai \& Horikoshi, 2000). These three species have been isolated from coastal and deep marine hydrothermal systems.

In this paper, the first isolation of a species of the genus 
Thermosipho from oilfield water is described. The phenotypic and genetic characteristics of the novel strain are consistent with its placement in a new species of the genus Thermosipho, which is named Thermosipho geolei sp. nov.

\section{METHODS}

Source of organisms. The novel strain was isolated from an oil/water mixture taken directly from a production wellhead of a deep continental petroleum reservoir in Western Siberia (Russia). Thermosipho africanus $\mathrm{Ob}^{\mathrm{T}}$ (= DSM $5309^{\mathrm{T}}$ ) was obtained from the DSMZ. Thermosipho melanesiensis $\mathrm{BI} 429^{\mathrm{T}}$ (= DSM $12029^{\mathrm{T}}$ ) was kindly provided by the Laboratoire de Caractérisation des Micro-organismes Marins (Ifremer, Brest, France).

Enrichment, isolation and growth conditions. Enrichments were performed anaerobically in Hungate tubes containing $10 \mathrm{ml}$ medium, according to Balch \& Wolfe (1976). The enrichment medium consisted of $\left(1^{-1}\right.$ distilled water): $20 \mathrm{~g} \mathrm{NaCl}, 0.33 \mathrm{~g} \mathrm{NH}_{4} \mathrm{Cl}, 0.33 \mathrm{~g} \mathrm{KH}_{2} \mathrm{PO}_{4}, 0.33 \mathrm{~g}$ $\mathrm{MgCl}_{2} \cdot 6 \mathrm{H}_{2} \mathrm{O}, \quad 0.33 \mathrm{~g} \mathrm{CaCl}_{2} .2 \mathrm{H}_{2} \mathrm{O}, \quad 1 \mathrm{~g} \mathrm{NaHCO}_{3}, 2 \mathrm{~g}$ sodium acetate, $0.5 \mathrm{~g}$ yeast extract, $0.5 \mathrm{~g} \mathrm{Na}{ }_{2} \mathrm{~S} .9 \mathrm{H}_{2} \mathrm{O}, 1 \mathrm{ml}$ trace element solution (Kevbrin \& Zavarzin, 1992) and $2 \mathrm{ml}$ vitamin solution (Wolin et al., 1963), and had a $\mathrm{pH}$ at room temperature of $6 \cdot 8-7 \cdot 0$. It was inoculated with $1 \mathrm{ml}$ oil/water sample, pressurized with $\mathrm{N}_{2}(100 \% ; 100 \mathrm{kPa})$ and incubated without shaking at $65^{\circ} \mathrm{C}$. The medium used to grow the type strains and to isolate and to cultivate strain $\mathrm{SL} 31^{\mathrm{T}}$ routinely contained $\left(1^{-1}\right.$ distilled water): $15 \mathrm{~g} \mathrm{NaCl}$, $0.5 \mathrm{~g} \mathrm{MgCl}_{2} .6 \mathrm{H}_{2} \mathrm{O}, 3 \cdot 4 \mathrm{~g}$ PIPES, $0.2 \mathrm{~g} \mathrm{KCl}, 1 \mathrm{~g} \mathrm{NH} 4 \mathrm{Cl}, 0 \cdot 1 \mathrm{~g}$ $\mathrm{CaCl}_{2} .2 \mathrm{H}_{2} \mathrm{O}, 0 \cdot 35 \mathrm{~g} \mathrm{~K}_{2} \mathrm{HPO}_{4}, 0 \cdot 35 \mathrm{~g} \mathrm{KH}_{2} \mathrm{PO}_{4}, 2 \cdot 72 \mathrm{~g}$ sodium acetate trihydrate, $2 \mathrm{~g}$ yeast extract, $2 \mathrm{~g}$ bio-Trypcase (bioMérieux) and $1 \mathrm{mg}$ resazurin. The $\mathrm{pH}$ was adjusted to $7 \cdot 0$ using $5 \mathrm{M} \mathrm{HCl}$ before autoclaving. Prior to inoculation, maltose and $\mathrm{Na}_{2} \mathrm{~S} .9 \mathrm{H}_{2} \mathrm{O}$ were injected from sterile anaerobic stock solutions to obtain final concentrations of 0.2 and $0.1 \%$, respectively. Single colonies were obtained and purified by streaking on the same medium that was solidified with $1 \%(\mathrm{w} / \mathrm{v})$ Phytagel (a gellan gum from Sigma). Plates were incubated in anaerobic jars at $65^{\circ} \mathrm{C}$ under an $\mathrm{N}_{2} / \mathrm{CO}_{2}$ atmosphere $(80: 20 ; 100 \mathrm{kPa})$. Stock cultures of isolate SL $31^{\mathrm{T}}$ were stored in culture medium at $4{ }^{\circ} \mathrm{C}$. For long-term storage, pure cultures were stored at $-80^{\circ} \mathrm{C}$ in the same medium containing $10 \%(\mathrm{w} / \mathrm{v})$ DMSO.

Determination of growth parameters. Growth was monitored by measuring the increase of $\mathrm{OD}_{600}$ with a Spectronic 401 spectrophotometer (Bioblock). All growth experiments were performed in triplicate. The $\mathrm{pH}$ range for growth was determined in the culture medium with various buffers at a concentration of $10 \mathrm{mM}$ (MES for $\mathrm{pH} 5 \cdot 0-6 \cdot 0$, PIPES for $\mathrm{pH} 6.5$ and 7.0, HEPES for $\mathrm{pH} 7 \cdot 5$, Tris for $\mathrm{pH} 8 \cdot 0$ and $8 \cdot 5$ ). Appropriate amounts of $1 \mathrm{M} \mathrm{Na}_{2} \mathrm{CO}_{3}$ were added to adjust the $\mathrm{pH}$ of the medium to $9 \cdot 0$ and $9 \cdot 5 \mathrm{pH}$ values were determined at room temperature. To determine the optimum $\mathrm{NaCl}$ range for growth, $\mathrm{NaCl}$ concentrations were varied while maintaining the concentrations of the other inorganic components. The effects of different $\mathrm{pH}$ values and concentrations of $\mathrm{NaCl}$ were determined at $70^{\circ} \mathrm{C}$.

Substrate utilization tests. Ability to grow lithoautotrophically was tested in the basal medium where yeast extract, bioTrypcase, acetate and maltose were omitted and with $\mathrm{H}_{2} / \mathrm{CO}_{2}(80: 20 ; 100 \mathrm{kPa})$ as the gas phase. Possible growth substrates were tested in the same medium and substrates were added at a concentration of $500 \mathrm{mg} \mathrm{l}^{-1}$ with $\mathrm{N}_{2}(100 \%$;
$100 \mathrm{kPa}$ ) as the gas phase. Three consequent transfers were performed on each substrate that allowed growth. The influence of yeast extract on growth with substrates was tested by adding this compound to the basal medium at a concentration of $50 \mathrm{mg} \mathrm{l}^{-1}$. The influence of elemental sulfur on the utilization of substrates was tested in the same medium with $50 \mathrm{mg}$ yeast extract $1^{-1}$ and $1 \%$ elemental sulfur.

Effects of electron acceptors on growth, glucose metabolism and hydrogen and oxygen susceptibility. Elemental sulfur $(1 \%)$, cystine $(1 \%)$, sulfate $(20 \mathrm{mM})$ and thiosulfate $(20 \mathrm{mM})$ were tested as potential electron acceptors in the culture medium. The influence of elemental sulfur on growth and on the amounts of acetate and L-alanine produced during glucose fermentation was investigated according to the method of Ravot et al. (1996a,b). Amino acid concentrations were determined by liquid chromatography (Moore et al., 1958). The influence of hydrogen on growth was examined in medium supplemented with or without elemental sulfur under $\mathrm{H}_{2} / \mathrm{CO}_{2}(80: 20 ; 100 \mathrm{kPa})$ and under $\mathrm{N}_{2} / \mathrm{CO}_{2}(80: 20 ; 100 \mathrm{kPa})$. Susceptibility to oxygen was tested by incubating the organism in culture medium at $70{ }^{\circ} \mathrm{C}$ under aerated and under microaerophilic conditions (L’Haridon et al., 1998).

Antibiotic susceptibility. Sensitivity of strain SL31 ${ }^{\mathrm{T}}$ to chloramphenicol, streptomycin, vancomycin and rifampicin (all from Sigma) was tested at $70^{\circ} \mathrm{C}$. Simultaneous experiments were performed with Thermosipho africanus $\mathrm{Ob}^{\mathrm{T}}$ and Thermosipho melanesiensis $\mathrm{BI} 429^{\mathrm{T}}$ at the same temperature.

Light and electron microscopy. An Olympus BX-60 microscope equipped with an Olympus OM-2 camera was used routinely to observe and to obtain photomicrographs. For negative staining, $20 \mu \mathrm{l}$ cell suspension, fixed with $2 \%(\mathrm{w} / \mathrm{v})$ glutaraldehyde, was dropped on Formvar/carbon-coated grids (400 mesh) and stained with $2 \%$ phosphotungstate. Thin sections were prepared as described previously (BonchOsmolovskaya et al., 1990). Electron micrographs were taken using a model JEM-100 electron microscope.

$\mathrm{H}_{2} \mathrm{~S}$ production. $\mathrm{H}_{2} \mathrm{~S}$ production was evaluated by adding $500 \mu \mathrm{l}$ solution containing $\mathrm{CuSO}_{4}(5 \mathrm{mM})$ and $\mathrm{HCl}(50 \mathrm{mM})$ to $250 \mu$ culture grown at $65^{\circ} \mathrm{C}$. The dark-brown precipitate demonstrating the presence of sulfide was compared with that of the uninoculated medium incubated under the same conditions. Sulfide was determined photometrically as colloidal CuS by using the method of Cord-Ruwisch (1985).

DNA extraction and base composition. Genomic DNA of strain SL $31^{\mathrm{T}}$ was isolated by using the procedure described by Charbonnier \& Forterre (1994). The DNA was purified on a caesium chloride gradient (Sambrook et al., 1989) and purity was checked spectrophotometrically. The $\mathrm{G}+\mathrm{C}$ content of the DNA was determined from the melting point according to Marmur \& Doty (1962) using as standards DNA from Escherichia coli $(\mathrm{G}+\mathrm{C}$ content $52 \mathrm{~mol} \%)$, Clostridium perfringens $(24 \mathrm{~mol} \%)$ and Micrococcus luteus (73 mol\%) (all from Sigma).

165 rDNA-based phylogenetic analysis. Extraction of genomic DNA, PCR-mediated amplification of the 16S rDNA and sequencing of the purified PCR product were carried out according to Rainey et al. (1996). The sequence reaction mixtures were electrophoresed using a model 373A automatic sequencer (Applied Biosystems). The 16S rDNA sequences were aligned with published sequences of the DSMZ database using the ae2 editor (Maidak et al., 1996) 
and sequences retrieved from EMBL. Evolutionary distances were calculated by the method of Jukes \& Cantor (1969). Distance analysis dendrograms were reconstructed as described by De Soete (1983). Bootstrap analysis was used to evaluate the tree topology after neighbour-joining by performing 500 resamplings (Felsenstein, 1985).

DNA-DNA hybridization experiments. Genetic relatedness was investigated by slot-blot DNA-DNA hybridization by using a random-prime labelling and signal amplification system (Amersham Life Sciences) following the procedure described by Kristjánsson et al. (1994). Increasing amounts of target DNA (50-100 ng) denatured in 0.4 M NaOH were slotted onto a nylon hybridization membrane (Bio-Rad) and probed with $200 \mathrm{ng}$ labelled tracer DNA. For each duplicate of DNA-DNA association ( $15 \mathrm{~h}$ in $4 \times$ SSC buffer with formamide, $0.5 \%$ blocking agent, $5 \%$ dextran sulfate, $100 \mu \mathrm{g}$ denatured sheared salmon sperm DNA ml ${ }^{-1}$ ), the temperature of hybridization chosen was in the optimal range of the hybridization buffer (Johnson, 1984; Ivanova et al., 1988). Final highly stringent washes and signal amplification were performed according to the manufacturer's instructions. Hybridization signals were detected with a Storm fluorescent scanner (Molecular Dynamics) and analysed by using the IMAGE-QUANT program. The signal (maximum peak area) produced by self-hybridization of the probe with homologous target DNA was set as $100 \%$ and compared with the signal generated by heterologous DNA.

\section{RESULTS}

\section{Enrichments and isolation}

Stratal fluids from different horizons of the Samotlor oilfield (1700-2500 $\mathrm{m}$ depth), having temperatures of $45-84{ }^{\circ} \mathrm{C}$, were taken directly from production wellheads through a tap fitted on the production line. Stratal waters had a total mineral content of 5.7$32.9 \mathrm{~g} \mathrm{l}^{-1}$ and a $\mathrm{pH}$ of $5 \cdot 5-7 \cdot 5$. Some sites of the Samotlor oilfield are exploited by flooding with a mixture of freshwater from the Vah river (about 30\%) and production water. The temperature of the injection water was $4-40^{\circ} \mathrm{C}$ depending on the season. The salinity of injection water was 9-17 $\mathrm{g} \mathrm{l}^{-1}$. Enrichments of thermophiles were performed by inoculating the collected production fluids into anaerobic enrichment medium and incubating at $65^{\circ} \mathrm{C}$. Within $2 \mathrm{~d}$, turbidity due to cell growth was observed. This growth consisted of small, rod-shaped bacteria with a characteristic outer sheath-like structure. The sheathed bacteria were purified by streaking subcultures onto solidified medium and incubating in an anaerobic jar at $65^{\circ} \mathrm{C}$. After $3 \mathrm{~d}$, whitish round colonies (1-2 mm in diameter) were obtained. Three single colonies were picked and the isolation procedure was repeated at least three times before each of the isolates, designated SL30, SL31 ${ }^{\mathrm{T}}$ and MLM39636, was considered to be pure. Isolate SL31 ${ }^{\mathrm{T}}$ was studied in detail.

\section{Morphology}

Cells of isolate SL $31^{\mathrm{T}}$ were rod-shaped with a length of about $2-3 \mu \mathrm{m}$ and a width of about $0 \cdot 4-0.6 \mu \mathrm{m}$ (Fig. 1a). In the very early exponential phase of growth, no sheaths could be distinguished clearly around single cells by phase-contrast or transmission electron microscopy (Fig. 1a). Although motility has not been observed under phase microscopy, some of the negatively stained, unsheathed cells examined by transmission electron microscopy possessed single polar flagella (Fig. 1a). After the mid-exponential phase of growth, an envelope surrounding the cells was readily visible by phase-contrast and electron microscopy and cells became longer (Fig. 1b). No flagella could be detected on sheathed cells (data not shown). In the stationary growth phase, the sheaths and cells grew longer and envelopes containing four to six cells were observed. In addition, some of the rods became spheres. Thin sections revealed the Gram-negative structure of the cell wall, with an outer membrane (Fig. $1 \mathrm{c}$ and $\mathrm{d})$.

\section{Determination of growth parameters}

Strain SL31 ${ }^{\mathrm{T}}$ grew between 45 and $75^{\circ} \mathrm{C}$, with optimum growth around $70^{\circ} \mathrm{C}$; no growth was observed at 40 or $80^{\circ} \mathrm{C}$ (Fig. 2a). Growth was observed between $\mathrm{pH} 6.0$ and 9.4 , with optimum growth around $\mathrm{pH} 7.5$ (Fig. 2b). Growth occurred at $\mathrm{NaCl}$ concentrations of 5-70 $\mathrm{g} \mathrm{l}^{-1}$, with an optimum between 20 and $30 \mathrm{~g} \mathrm{l}^{-1}$ (Fig. 2c); no growth was observed at 0 or $80 \mathrm{~g}^{-1}$. Under optimal growth conditions (temperature, $\mathrm{pH}$ and $\mathrm{NaCl}$ ), the doubling time of strain $\mathrm{SL} 31^{\mathrm{T}}$ was approximately $115 \mathrm{~min}$.

\section{Substrates used for growth}

Strain SL31 ${ }^{\mathrm{T}}$ was a strictly anaerobic, organotrophic organism. Its growth was prevented in the presence of low levels of oxygen $(0 \cdot 2-1 \cdot 0 \%, \mathrm{v} / \mathrm{v})$ and under the autotrophic culture conditions tested. Strain SL31 ${ }^{\mathrm{T}}$ showed good growth with peptides like beef extract, peptone, papaic digest of soybean meal and yeast extract. Growth occurred on glucose in the presence of yeast extract $\left(50 \mathrm{mg} \mathrm{l}^{-1}\right)$. Casein, fructose, galactose, ribose, arabinose, xylose, maltose, sucrose, starch, xylan, cellulose, pyruvate, succinate, formate, acetate and methanol did not support growth, even when combined with yeast extract $\left(50 \mathrm{mg}^{-1}\right)$ or sulfur.

\section{Metabolic products}

Molecular hydrogen, acetate, alanine and $\mathrm{CO}_{2}$ were the main metabolic products detected after glucose fermentation, irrespective of the presence of sulfur (Table 1). In the absence of sulfur, small amounts of fructose $(0.6 \mathrm{mM})$ and isovalerate $(1.1 \mathrm{mM})$ were produced. These products were not detected in the presence of sulfur. Other volatile fatty acids, including branched-chain ones, and alcohols were not detected. In all cases, about $1 \mathrm{~mol} \mathrm{CO}_{2}(\mathrm{~mol} \text { acetate produced })^{-1}$ was produced. 


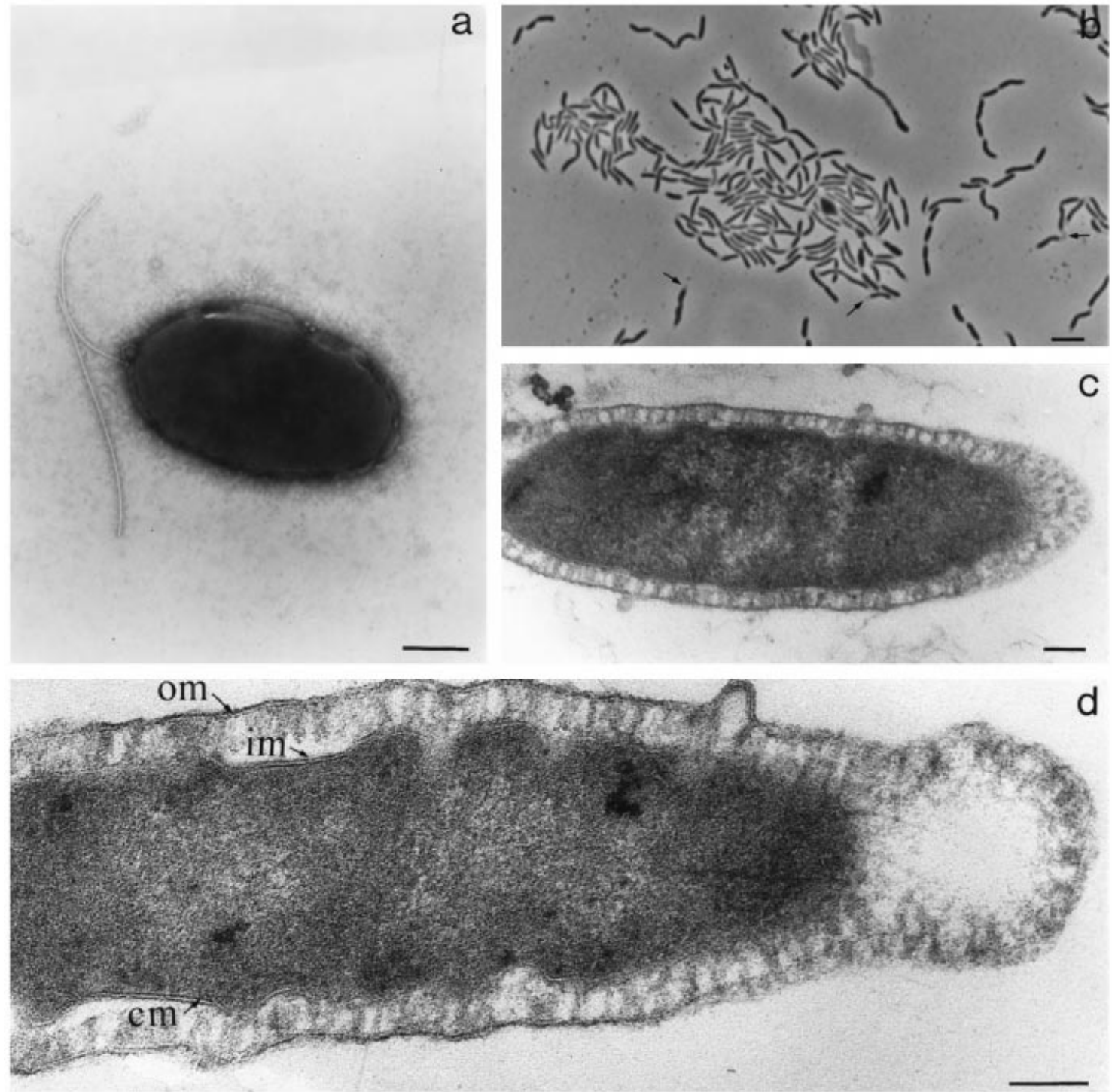

Fig. 1. (a) Electron micrograph of a negatively stained unsheathed cell of strain $S L 31^{\top}$, showing a polar flagellum. Bar, $500 \mathrm{~nm}$. (b) Phase-contrast micrograph of strain $S L 31^{\top}$ in late exponential phase of growth, showing chains of cells surrounded by the typical outer sheath-like structure (arrows). Bar, $5 \mu \mathrm{m}$. (c, d) Thin sections of strain SL31 $1^{\top}$ showing a typical Gram-negative cell wall ultrastructure. om, Outer membrane; im, inner membrane; cm, cytoplasmic membrane. Bars, $100 \mathrm{~nm}$.

\section{Influence of sulfur compounds on growth and on glucose metabolism}

Growth of SL31 ${ }^{\mathrm{T}}$ was inhibited completely by $\mathrm{H}_{2}$ in the headspace [gas phase $\mathrm{H}_{2} / \mathrm{CO}_{2}(80: 20 ; 100 \mathrm{kPa})$ ]. Inhibition of growth by $\mathrm{H}_{2}$ was overcome by the addition of sulfur. Addition of sulfur stimulated growth, with the concomitant production of $\mathrm{H}_{2} \mathrm{~S}$ (Table 1). Similar results were obtained with Thermosipho melanesiensis $\mathrm{BI} 429^{\mathrm{T}}$ and Thermosipho africanus $\mathrm{Ob}^{\mathrm{T}}$, used for comparative studies. Strain SL31 ${ }^{\mathrm{T}}$, Thermosipho melanesiensis $\mathrm{BI} 429^{\mathrm{T}}$ and Thermosipho africanus $\mathrm{Ob}^{\mathrm{T}}$ were unable to reduce sulfate to $\mathrm{H}_{2} \mathrm{~S}$ in the presence of $\mathrm{H}_{2}$. Of these strains, only Thermosipho africanus $\mathrm{Ob}^{\mathrm{T}}$ was able to reduce thiosulfate. The presence of sulfur as an electron acceptor, lowering the hydrogen partial pressure of the medium, also had an effect on the alanine/acetate and alanine/glucose ratios produced during glucose fermentation. When elemental sulfur was absent, the alanine/acetate and alanine/glucose ratios were about $0 \cdot 14$ and $0 \cdot 16$, respectively. In the presence of elemental sulfur, both ratios decreased to values of about 0.07-0.08 (Table 1).

\section{Sensitivity to antibiotics}

Strain SL31 ${ }^{\mathrm{T}}$ and Thermosipho melanesiensis BI429 ${ }^{\mathrm{T}}$ were sensitive to chloramphenicol $\left(10 \mu \mathrm{g} \mathrm{ml}^{-1}\right)$, whereas Thermosipho africanus $\mathrm{Ob}^{\mathrm{T}}$ was resistant at 

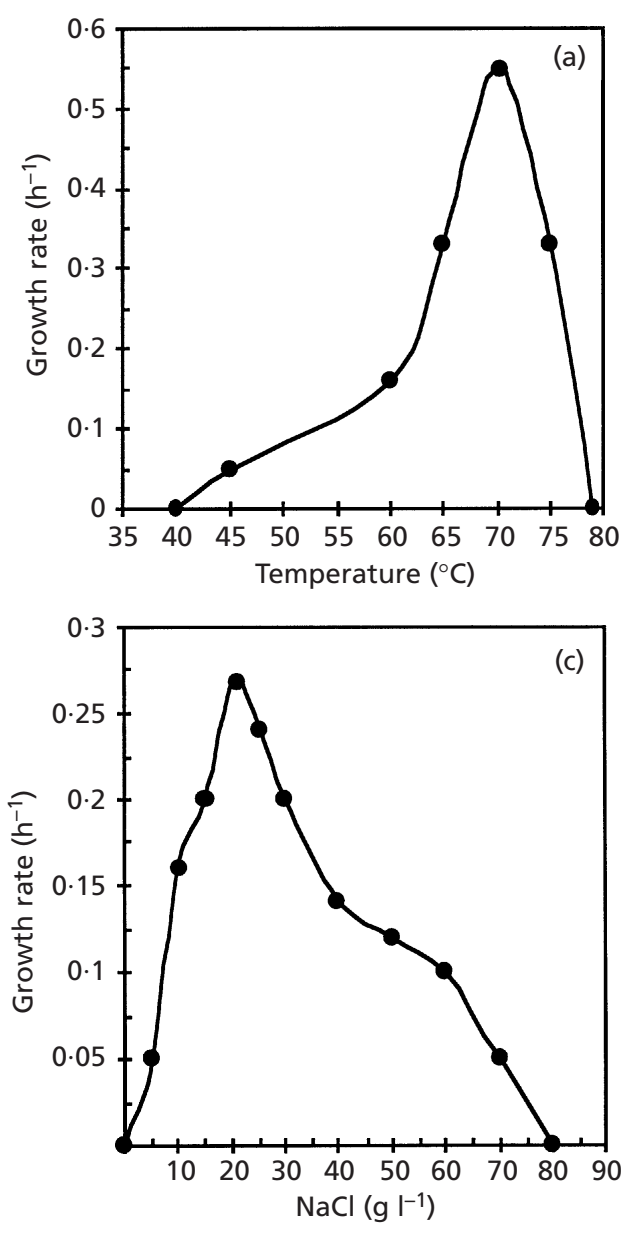

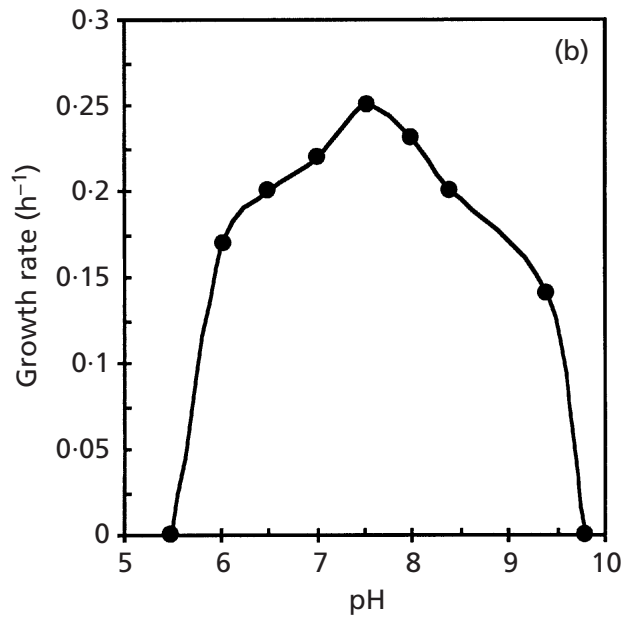

Fig. 2. Specific growth rates $(\mu)$ of strain $\mathrm{SL} 31^{\top}$ as a function of temperature in the presence of $15 \mathrm{~g} \mathrm{NaCl} \mathrm{I}^{-1}$ and at $\mathrm{pH} 7$ (a), as a function of $\mathrm{pH}$ at $70^{\circ} \mathrm{C}$ and in the presence of $15 \mathrm{~g} \mathrm{NaCl} \mathrm{I}^{-1}$ (b) and as a function of concentration of $\mathrm{NaCl}$ at $70^{\circ} \mathrm{C}$ and at $\mathrm{pH} 7$ (c).

Table 1. Fermentation of glucose by strain $\mathrm{SL} 31^{\top}$ in the presence or absence of sulfur

The results shown were obtained after 1 month of incubation at $70{ }^{\circ} \mathrm{C}$. Uninoculated controls did not exhibit $\mathrm{H}_{2} \mathrm{~S}$ production in the presence or absence of sulfur.

\begin{tabular}{|c|c|c|c|c|c|c|c|}
\hline \multirow[t]{2}{*}{ Culture conditions } & \multirow[t]{2}{*}{$\begin{array}{l}\text { Amount of substrate } \\
\text { utilized (mmol) }\end{array}$} & \multicolumn{4}{|c|}{$\begin{array}{c}\text { Amount of end } \\
\text { product formed (mmol) }\end{array}$} & \multicolumn{2}{|c|}{$\begin{array}{l}\text { Molar ratio of product } \\
\text { produced to sugar consumed }\end{array}$} \\
\hline & & $\mathrm{H}_{2}{ }^{*}$ & $\mathrm{H}_{2} \mathrm{~S}$ & Acetate & Alanine & Acetate & Alanine \\
\hline Glucose & $7 \cdot 3$ & $9 \cdot 3$ & $0 \cdot 5$ & $8 \cdot 5$ & $1 \cdot 2$ & $1 \cdot 20$ & $0 \cdot 16$ \\
\hline Glucose $+\mathrm{S}^{0}$ & $6 \cdot 0$ & 0 & $12 \cdot 5$ & $7 \cdot 5$ & $0 \cdot 5$ & $1 \cdot 25$ & $0 \cdot 08$ \\
\hline
\end{tabular}

* Amount of $\mathrm{H}_{2}$ produced in millimolar equivalents.

this concentration. The three strains were resistant to vancomycin $\left(100 \mu \mathrm{g} \mathrm{ml}^{-1}\right)$ and to streptomycin and rifampicin $\left(10 \mu \mathrm{g} \mathrm{ml}^{-1}\right)$, but were inhibited by the latter compounds at concentrations of $100 \mu \mathrm{g} \mathrm{ml}^{-1}$.

\section{$16 S$ rDNA sequence analysis}

$16 \mathrm{~S}$ rDNA sequence analysis showed that strain SL31 ${ }^{\mathrm{T}}$ was a close relative of Thermosipho africanus $\mathrm{Ob}^{\mathrm{T}}$ (96.4\% similarity), Thermosipho japonicus $\mathrm{IHB}^{\mathrm{T}}$
(96.3\% similarity), strain RI 19.B2 (93.8\% similarity) and Thermosipho melanesiensis $\mathrm{BI} 429^{\mathrm{T}}(92.3 \%$ similarity). Members of other genera of the "Thermotogaceae' showed lower similarity values. Phylogenetic trees generated using distance algorithms and maximum-likelihood analysis gave the same topology. The bootstrap values from 500 samplings confirmed the affiliation of strain SL31 ${ }^{\mathrm{T}}$ to a clade (monophyletic taxon) that also included Thermosipho africanus $\mathrm{Ob}^{\mathrm{T}}$, strain RI 19.B2, Thermosipho japonicus $\mathrm{IHB}^{\mathrm{T}}$ and 


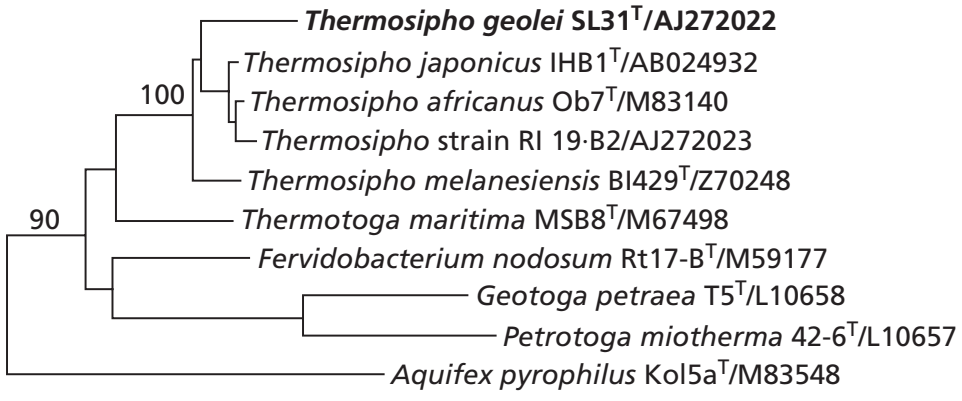

$10 \%$
Fig. 3. $16 \mathrm{~S}$ rDNA sequence-based phylogenetic distance analysis dendrogram showing the phylogenetic position of strain $\mathrm{SL} 31^{\top}\left(=\mathrm{DSM} 13257^{\top}\right)$ and related species in the genus Thermosipho and other members of the order 'Thermotogales'. The sequence of Aquifex pyrophilus served as an outside reference. Bar, 10 inferred nucleotide substitutions per 100 nucleotides. Numbers at branching points refer to bootstrap values $(>70 \%)$. Accession numbers are given for each sequence.
Thermosipho melanesiensis BI429 ${ }^{\mathrm{T}}$ (Fig. 3). Based upon partial 16S rDNA sequences $(500 \mathrm{nt})$, strains SL31 ${ }^{\mathrm{T}}$ and SL30 were identical.

\section{DNA base composition and DNA-DNA hybridization}

The $\mathrm{G}+\mathrm{C}$ content of the DNA of isolate $\mathrm{SL} 31^{\mathrm{T}}$ was $30.0 \mathrm{~mol} \%$ as determined by the thermal denaturation method. No significant relatedness was obtained between bulk cellular DNA of the isolate $\mathrm{SL} 31^{\mathrm{T}}$ and that from Thermosipho africanus $\mathrm{Ob}^{\mathrm{T}}$ or Thermosipho melanesiensis $\mathrm{BI} 429^{\mathrm{T}}$ (mean hybridization values $<10 \%$ ). High relatedness (mean hybridization values $>80 \%$ ) was found between strain SL31 ${ }^{\mathrm{T}}$ and isolates SL30 and MLM39636.

\section{DISCUSSION}

The novel isolate $\mathrm{SL} 31^{\mathrm{T}}$ is an obligately anaerobic, heterotrophic bacterium with a typical Gram-negative cell wall ultrastructure. This organism exhibited characteristics similar to those described for representatives of the order 'Thermotogales', i.e. fermentative thermophiles that are rod-shaped and have the characteristic sheath-like outer structure referred to as a toga. Several features affiliated strain SL $31^{\mathrm{T}}$ with the genus Thermosipho, as represented by three species, Thermosipho africanus (Huber et al., 1989), Thermosipho melanesiensis (Antoine et al., 1997) and Thermosipho japonicus (Takai \& Horikoshi, 2000): (i) possible growth of cells in chains, surrounded by a common sheath; (ii) a DNA G + C content of 30.0-31.4 mol \% ; and (iii) its $16 \mathrm{~S}$ rRNA similarity to these organisms. However, several phenotypic characters differentiated strain SL31 $1^{\mathrm{T}}$ from the three described Thermosipho species. The novel isolate differed from the three species by the presence of a polar flagellum visible on single cells in the early exponential phase of growth. It differed from Thermosipho africanus by its lower temperature optimum, its higher $\mathrm{pH}$ and salinity maxima for growth and its inability to grow on sugars other than glucose and to reduce thiosulfate. SL31 ${ }^{\mathrm{T}}$ differed from Thermosipho melanesiensis by its lower temperature maximum and $\mathrm{pH}$ minimum for growth and its inability to utilize a wide range of sugars. It differed from Thermosipho japonicus by the white colour of its colonies, its lower salinity optimum and its inability to grow on casein and sugars other than glucose and to reduce thiosulfate. 16S rDNA analysis indicated that SL31 ${ }^{\mathrm{T}}$ is most closely related to Thermosipho africanus $\mathrm{Ob}^{\mathrm{T}}$. However, a low level of genetic relatedness between the two strains was determined by DNA-DNA hybridization studies, indicating that these organisms cannot be assigned to the same species (Johnson, 1984). Similarly, weak levels of DNA-DNA hybridization were measured between strain SL31 $1^{\mathrm{T}}$ and Thermosipho melanesiensis. It is considered that strain SL31 ${ }^{\mathrm{T}}$ is phenotypically, phylogenetically and genomically sufficiently different from the three previously described Thermosipho species to be proposed as a member of a new species of the genus Thermosipho.

Up to now, the described Thermosipho species have been isolated from coastal and deep-sea hydrothermal vents (Huber et al., 1989; Antoine et al., 1997; Takai \& Horikoshi, 2000). A description of the first organism belonging to this genus that has been isolated from a deep petroleum reservoir is given here. Cultural and molecular studies have also revealed that other phylogenetically diverse members of the 'Thermotogales' thrive in the continental deep oil reservoir of Western Siberia sampled in this study (Slobodkin et al., 1999; E. A. Bulygina, Y. P. Lysov, N. A. Chernyh, A. V. Lebedinski, E. A. Bonch-Osmolovskaya, H. Hippe, S. L'Haridon, C. Jeanthon \& A. D. Mirzabekov, unpublished results).

\section{Description of Thermosipho geolei sp. nov.}

Thermosipho geolei (ge.o'le.i. Gr. n. ge earth; L. gen. neut. n. olei of oil; N.L. gen. neut. n. geolei from earth oil, referring to the site of isolation).

Cells are Gram-negative rods with a length of about $2-3 \mu \mathrm{m}$ and a width of about $0 \cdot 4-0 \cdot 6 \mu \mathrm{m}$. No motility is observed under the microscope. A polar flagellum is inserted on unsheathed cells in the very early exponential phase of growth. A sheath-like structure is clearly visible after the mid-exponential phase of growth. Cells form enlarged spherical bodies in stationary phase. They occur singly, in pairs or in chains of a maximum of six cells. White colonies, 
about $1-2 \mathrm{~mm}$ in diameter, are formed on 'Phytagel' plates. Growth occurs between 45 and $75^{\circ} \mathrm{C}$ (optimum growth at $70{ }^{\circ} \mathrm{C}$; doubling time of $115 \mathrm{~min}$ ), between $\mathrm{pH} 6.0$ and 9.4 (optimum growth at approximately $\mathrm{pH}$ 7.5 ) and at $\mathrm{NaCl}$ concentrations between 0.5 and $7.0 \%$ (optimum growth between 2 and $3 \%$ ). Strictly anaerobic. $\mathrm{H}_{2}$ inhibits growth but inhibition is alleviated by addition of elemental sulfur; under these conditions, hydrogen sulfide is produced. Neither thiosulfate nor sulfate can be used as electron acceptors. Metabolism shifts to alanine production in the absence of elemental sulfur. Growth is inhibited by chloramphenicol $\left(10 \mu \mathrm{g} \mathrm{ml}^{-1}\right)$, vancomycin and rifampicin (both at a final concentrations of $100 \mu \mathrm{g} \mathrm{m}^{-1}$ ); growth occurs in the presence of streptomycin $\left(100 \mu \mathrm{g} \mathrm{ml}^{-1}\right)$. DNA $\mathrm{G}+\mathrm{C}$ composition of the type strain is $30.0 \mathrm{~mol} \%$ (thermal denaturation method). Phylogenetic analysis based on the complete 16S rRNA sequence affiliates the strain conclusively with the 'Thermotogales' and, more specifically, with the genus Thermosipho. No significant bulk DNA similarity to Thermosipho africanus or Thermosipho melanesiensis. The type strain is SL31 $1^{\mathrm{T}}\left(=\mathrm{DSM} 13256^{\mathrm{T}}=\mathrm{JCM}\right.$ $10986^{\mathrm{T}}$ ), obtained from an oil/water mixture collected from a deep continental oil reservoir in Western Siberia (Russia).

\section{ACKNOWLEDGEMENTS}

We thank Tamara Nazina, Nikolai Chernyh and the Russian Samotlor oil company for sample collection. This work was supported by Intas (project 96-1341).

\section{REFERENCES}

Achenbach-Richter, L., Gupta, R., Stetter, K. O. \& Woese, C. R. (1987). Were the original eubacteria thermophiles? Syst Appl Microbiol 9, 34-39.

Andrews, K. T. \& Patel, B. K. C. (1996). Fervidobacterium gondwanense sp. nov., a new thermophilic anaerobic bacterium isolated from nonvolcanically heated geothermal waters of the Great Artesian Basin of Australia. Int J Syst Bacteriol 46, 265-269.

Antoine, E., Cilia, V., Meunier, J. R., Guezennec, J., Lesongeur, F. \& Barbier, G. (1997). Thermosipho melanesiensis sp. nov., a new thermophilic anaerobic bacterium belonging to the order 'Thermotogales', isolated from deep-sea hydrothermal vents in the southwestern Pacific Ocean. Int J Syst Bacteriol 47, $1118-1123$.

Balch, W. E. \& Wolfe, R. S. (1976). New approach to the cultivation of methanogenic bacteria: 2-mercaptoethanesulfonic acid (HS-CoM)-dependent growth of Methanobacterium ruminantium in a pressurized atmosphere. Appl Environ Microbiol 32, 781-791.

Bonch-Osmolovskaya, E. A., Sokolova, T. G., Kostrikina, N. A. \& Zavarzin, G. A. (1990). Desulfurella acetivorans gen. nov. and sp. nov. - a new thermophilic sulfur-reducing bacterium. Arch Microbiol 153, 151-155.

Burgraff, S., Olsen, G. J., Stetter, K. O. \& Woese, C. R. (1992). A phylogenetic analysis of Aquifex pyrophilus. Syst Appl Microbiol 15, 352-356.

Charbonnier, F. \& Forterre, P. (1994). Comparison of plasmid
DNA topology among mesophilic and thermophilic eubacteria and archaebacteria. J Bacteriol 176, 1251-1259.

Cord-Ruwisch, R. (1985). A quick method for the determination of dissolved and precipitated sulfides in cultures of sulfatereducing bacteria. J Microbiol Methods 4, 33-36.

Corre, E. (2000). Approches moléculaires de la diversité microbienne de deux environnements extrêmes: les sources hydrothermales profondes et les réservoirs pétroliers. $\mathrm{PhD}$ thesis, Université de Bretagne Occidentale

Davey, M. E., Wood, W. A., Key, R., Nakamura, K. \& Stahl, D. (1993). Isolation of three species of Geotoga and Petrotoga: two new genera, representing a new lineage in the bacterial line of descent distantly related to the 'Thermotogales'. Syst Appl Microbiol 16, 191-200.

De Soete, G. (1983). A least squares algorithm for fitting additive trees to proximity data. Psychometrika 48, 621-626.

Fardeau, M.-L., Ollivier, B., Patel, B. K. C., Magot, M., Thomas, P., Rimbault, A., Rocchiccioli, F. \& Garcia, J.-L. (1997). Thermotoga hypogea sp. nov., a xylanolytic, thermophilic bacterium from an oil-producing well. Int J Syst Bacteriol 47, 1013-1019.

Felsenstein, J. (1985). Confidence limits on phylogenies: an approach using the bootstrap. Evolution 39, 783-791.

Grassia, G. S., McLean, K. M., Glénat, P., Bauld, J. \& Sheehy, A. J. (1996). A systematic survey for thermophilic fermentative bacteria and archaea in high temperature petroleum reservoirs. FEMS Microbiol Ecol 21, 47-58.

Harmsen, H. J. M., Prieur, D. \& Jeanthon, C. (1997). Groupspecific $16 \mathrm{~S}$ rRNA-targeted oligonucleotide probes to identify thermophilic bacteria in marine hydrothermal vents. Appl Environ Microbiol 63, 4061-4068.

Huber, R. \& Stetter, K. O. (1992). The order 'Thermotogales'. In The Prokaryotes, 2nd edn, pp. 3809-3815. Edited by A. Balows, H. G. Trüper, M. Dworkin, W. Harder \& K.-H. Schleifer. New York: Springer.

Huber, R., Langworthy, T. A., König, H., Thomm, M., Woese, C. R., Sleytr, U. B. \& Stetter, K. O. (1986). Thermotoga maritima sp. nov. represents a new genus of unique extremely thermophilic eubacteria growing up to $90{ }^{\circ} \mathrm{C}$. Arch Microbiol 144, 324-333.

Huber, R., Woese, C. R., Langworthy, T. A., Fricke, H. \& Stetter, K. O. (1989). Thermosipho africanus gen. nov., represents a new genus of thermophilic eubacteria within the 'Thermotogales'. Syst Appl Microbiol 12, 32-37.

Huber, R., Woese, C. R., Langworthy, T. A., Kristjansson, J. K. \& Stetter, K. O. (1990). Fervidobacterium islandicum sp. nov., a new extremely thermophilic eubacterium belonging to the "Thermotogales'. Arch Microbiol 154, 105-111.

Ivanova, T. L., Turova, T. P. \& Antonov, A. S. (1988). DNA-DNA hybridization studies on some purple non-sulfur bacteria. Syst Appl Microbiol 10, 259-263.

Jannasch, H. W., Huber, R., Belkin, S. \& Stetter, K. O. (1988). Thermotoga neapolitana sp. nov. of the extremely thermophilic, eubacterial genus Thermotoga. Arch Microbiol 150, 103-104.

Jeanthon, C., Reysenbach, A.-L., L'Haridon, S., Gambacorta, A., Pace, N. R., Glénat, P. \& Prieur, D. (1995). Thermotoga subterranea sp. nov., a new thermophilic bacterium isolated from a continental oil reservoir. Arch Microbiol 164, 91-97.

Johnson, J. L. (1984). Nucleic acids in bacterial classification. In Bergey's Manual of Systematic Bacteriology, vol. 1, pp. 8-11. Edited by N. R. Krieg \& J. G. Holt. Baltimore: Williams \& Wilkins.

Jukes, T. H. \& Cantor, C. R. (1969). Evolution of protein mol- 
ecules. In Mammalian Protein Metabolism, vol. 3, pp. 21-132. Edited by H. N. Munro. New York: Academic Press.

Kevbrin, V. V. \& Zavarzin, G. A. (1992). The influence of sulfur compounds on the growth of halophilic homoacetic bacterium Acetohalobium arabaticum. Mikrobiologiya 61, 812-817.

Koch, R., Canganella, F., Hippe, H., Jahnke, K. D. \& Antranikian, G. (1997). Purification and properties of a thermostable pullulanase from a newly isolated thermophilic anaerobic bacterium, Fervidobacterium pennavorans Ven5. Appl Environ Microbiol 63, 1088-1094.

Kristjánsson, J. K., Hjörleifsdóttir, S., Marteinsson, V.T. \& Alfredsson, G. A. (1994). Thermus scotoductus, sp. nov., a pigment-producing thermophilic bacterium from hot tap water in Iceland and including Thermus sp. X-1. Syst Appl Microbiol 17, 44-50

L'Haridon, S., Reysenbach, A.-L., Glénat, P., Prieur, D. \& Jeanthon, C. (1995). Hot subterranean biosphere in a continental oil reservoir. Nature 377, 223-224.

L'Haridon, S., Cilia, V., Messner, P., Raguénès, G., Gambacorta, A., Sleytr, U. B., Prieur, D. \& Jeanthon, C. (1998). Desulfurobacterium thermolithotrophum gen. nov., sp. nov., a novel autotrophic, sulfur-reducing bacterium isolated from a deepsea hydrothermal vent. Int J Syst Bacteriol 48, 701-711.

Lien, T., Madsen, F., Rainey, F. A. \& Birkeland, N.-K. (1998). Petrotoga mobilis sp. nov., from a North Sea oil-production well. Int J Syst Bacteriol 48, 1007-1013.

Maidak, B. L., Olsen, G. J., Larsen, N., Overbeek, R., McCaughey, M. J. \& Woese, C. R. (1996). The Ribosomal Database Project (RDP). Nucleic Acids Res 24, 82-85.

Magot, M. (1996). Similar bacteria in remote oil fields. Nature 379, 681 .

Marmur, J. \& Doty, D. (1962). Determination of the base composition of deoxyribonucleic acid from its thermal denaturation temperature. $J$ Mol Biol 5, 109-118.

Moore, S., Spackman, D. H. \& Stein, W. H. (1958). Chromatography of amino acids on sulfonated polystyrene resins: an improved system. Anal Chem 30, 1158-1190.

Orphan, V. J., Taylor, L. T., Hafenbradl, D. \& Delong, E. F. (2000). Culture-dependent and culture-independent characterization of microbial assemblages associated with high-temperature petroleum reservoirs. Appl Environ Microbiol 66, 700-711.

Patel, B. K. C., Morgan, H. W. \& Daniel, R. M. (1985). Fervidobacterium nodosum gen. nov. and spec. nov., a new chemo- organotrophic, caldoactive, anaerobic bacterium. Arch Microbiol 141, 63-69.

Ravot, G., Magot, M., Fardeau, M.-L., Patel, B. K. C., Prensier, G., Egan, A., Garcia, J.-L. \& Ollivier, B. (1995). Thermotoga elfii sp. nov., a novel thermophilic bacterium from an African oilproducing well. Int J Syst Bacteriol 45, 308-314.

Ravot, G., Ollivier, B., Patel, B. K. C., Magot, M. \& Garcia, J.-L. (1996a). Emended description of Thermosipho africanus as a carbohydrate-fermenting species using thiosulfate as an electron acceptor. Int J Syst Bacteriol 46, 321-323.

Ravot, G., Ollivier, B., Fardeau, M.-L., Patel, B. K. C., Andrews, K. T., Magot, M. \& Garcia, J.-L. (1996b). L-Alanine production from glucose fermentation by hyperthermophilic members of the domains Bacteria and Archaea: a remnant of an ancestral metabolism? Appl Environ Microbiol 62, 2657-2659.

Rainey, F. A., Ward-Rainey, N., Kroppenstedt, R. M. \& Stackebrandt, E. (1996). The genus Nocardiopsis represents a phylogenetically coherent taxon and a distinct actinomycete lineage: proposal of Nocardiopsaceae fam. nov. Int J Syst Bacteriol 46, 1088-1092.

Sambrook, J., Fritsch, E. F. \& Maniatis, T. (1989). Molecular Cloning: a Laboratory Manual, 2nd edn. Cold Spring Harbor, NY : Cold Spring Harbor Laboratory.

Slobodkin, A. I., Jeanthon, C., L'Haridon, S., Nazina, T., Miroshnichenko, M. \& Bonch-Osmolovskaya, E. (1999). Dissimilatory reduction of $\mathrm{Fe}$ (III) by thermophilic bacteria and archaea in deep subsurface petroleum reservoirs of Western Siberia. Curr Microbiol 39, 99-102.

Stetter, K. O., Huber, R., Blöchl, E., Kurr, M., Eden, R. D., Fielder, M., Cash, H. \& Vance, I. (1993). Hyperthermophilic archaea are thriving in deep North Sea and Alaskan oil reservoirs. Nature 365, 743-745.

Takahata, Y., Nishijima, M., Hoaki, T. \& Maruyama, T. (2000). Distribution and physiological characteristics of hyperthermophiles in the Kubiki oil reservoir in Niigata, Japan. Appl Environ Microbiol 66, 73-79.

Takai, K. \& Horikoshi, K. (2000). Thermosipho japonicus sp. nov., an extremely thermophilic bacterium isolated from a deep-sea hydrothermal vent in Japan. Extremophiles 4, 9-17.

Windberger, E., Huber, R., Trincone, A., Fricke, H. \& Stetter, K. O. (1989). Thermotoga thermarum sp. nov. and Thermotoga neapolitana occurring in African continental solfataric springs. Arch Microbiol 151, 506-512.

Wolin, E. A., Wolin, M. J. \& Wolfe, R. S. (1963). Formation of methane by bacterial extracts. J Biol Chem 238, 2882-2888. 